\section{Development of a PCR-RFLP Method for Differentiation of Perkinsus olseni and $P$. honshuensis in the Manila Clam Ruditapes philippinarum}

\author{
Miki Takahashi, Tomoyoshi Yoshinaga*, \\ Tsukasa Waki, Jun Shimokawa \\ and Kazuo Ogawa
}

Department of Aquatic Bioscience, Graduate School of Agricultural and Life Sciences, The University of Tokyo, Tokyo 113-8657, Japan

(Received August 24, 2009)

\begin{abstract}
We developed a method using PCR-RFLP to differentiate Perkinsus olseni and $P$. honshuensis, the latter of which was recently discovered as a new species in Mie, Japan, in the Manila clam Ruditapes philippinarum. In normal gill samples spiked with cultured trophozoites of the parasites, the minimum infection levels that could be detected by this method were 100 cells per $10 \mathrm{mg}$ sample for $P$. olseni and one cell for $P$. honshuensis. Using this method, we found that clams from the western Seto Inland Sea were infected with both species of the parasites. This is the first report of $P$. honshuensis from areas outside the type locality of this species.
\end{abstract}

Key words: Perkinsus olseni, Perkinsus honshuensis, Ruditapes philippinarum, PCR-RFLP

Perkinsus olseni is a protozoan parasite that infects clams, abalones and several other bivalves, and gastropods ${ }^{1)}$. Infection of the Manila clam Ruditapes philippinarum with $P$. olseni has been reported in the Far East, including Japan, Korea, China, and southwestern Europe. The majority of Manila clam populations in Japan are infected with $P$. olseni ${ }^{2)}$. Furthermore, $P$. olseni is thought to have caused the decline in Manila clam production in Japan and Korea in the $1980 s^{3,4)}$. Recently, a new species of parasite, $P$. honshuensis, was described in Manila clams in Mie Prefecture $^{5}$. These two parasite species are morphologically similar. Thus, species identification is confounded as it requires establishment of clonal strains and sequencing of several genomic regions of clones, including internal transcribed spacer regions (ITS). To investigate the distribution of these parasites, a fast and

\footnotetext{
* Corresponding author

E-mail: atyoshi@mail.ecc.u-tokyo.ac.jp
}

convenient method for identification is needed. Furthermore, we had already launched a study on Perkinsus infection in Manila clams in the western Seto Inland Sea when $P$. honshuensis was first described. Thus, it was an urgent need to reveal whether the clam populations we investigated were infected with $P$. olseni only or co-infected with the both species.

Abollo et al. (2006) developed a polymerase chain reaction-restriction fragment length polymorphism (PCRRFLP) method to differentiate Perkinsus chesapeaki, $P$. marinus, $P$. olseni and $P$. mediterraneus ${ }^{6)}$. In this study, we developed a PCR-RFLP method to differentiate $P$. olseni and $P$. honshuensis. We then tested infection of the parasites in Manila clams from several localities in Japan.

\section{Materials and Methods}

We obtained clonal strains of $P$. olseni and $P$. honshuensis from the American Type Culture Collection (ATCC \# PRA 181 and PRA 177, respectively). The trophozoite cells of them were subcultured using a routine method in Perkinsus broth medium (ATCC medium 1886) according to the instruction by American Type Culture Collection.

We obtained Manila clams that were infected with $P$. olseni and/or $P$. honshuensis from three localities for PCR-RFLP analysis developed in this study. Two of the localities, a clam farm in Hiroshima Prefecture and a tidal flat in Oita Prefecture, are located in the western Seto Inland Sea. The third locality is a tidal flat located in Yatsushiro Bay, Kumamoto Prefecture. Based on our preliminary examinations, the clams from the western Seto Inland Sea were heavily infected with Perkinsus (prevalence 100\%, geometric mean intensity of infection $>10^{6}$ cells $/ g$ gill weight), while those from Yatsushiro Bay were very lightly infected (prevalence $44 \%$, geometric mean intensity of infection $\sim 10^{4}$ cells $/ g$ gill weight). The numbers of clams applied for the analysis were 3, 4 and 3 for the clam farm in Hiroshima, the tidal flat in Oita and the tidal flat in Kumamoto, respectively. We also obtained uninfected clams from Akkeshi, Hokkaido. We confirmed the absence of infection in clams from this locality during a preliminary examination using Ray's fluid thioglycolate medium method and Perkinsus genus-specific PCR ${ }^{1)}$.

We extracted DNA from cultured trophozoites and sample clams using a QIAmp DNA Mini Kit (Qiagen, USA), following the manufacturer's protocol. First, we centrifuged $(300 \times g, 5 \mathrm{~min}) 10$-day-old cultures of trophozoites of the two Perkinsus strains and extracted DNA from each pellet $\left(\sim 10^{5}\right.$ cells/pellet). As trophozoites of the two Perkinsus species frequently formed massive clusters in the medium, the cell density was measured as follows: $10 \mu \mathrm{L}$ of the pellet was resuspended in $90 \mu \mathrm{L}$ of PBS and passed through a 25G hypodermic 
needle to break up the cell clusters. The suspension was then diluted 100 times with $100 \%$ ethanol. Following this, we mounted 0.5 or $1 \mu \mathrm{L}$ of the suspension onto a slide and stained the trophozoite nuclei with DNAbinding dye (Hoechst 33342) diluted in SlowFade Gold antifade reagent (Invitrogen, USA). The cells were then counted under a fluorescence microscope. Second, we extracted DNA from normal (= uninfected) gill samples (10 mg each) spiked with $1-1 \times 10^{9}$ cultured trophozoites. Last, we extracted DNA from $10 \mathrm{mg}$ of the gills of cultured or wild Manila clams (shell length 7-18 $\mathrm{mm}$ ) obtained from the two localities in the western Seto Inland Sea and one locality in Yatsushiro Bay.

For PCR amplification, we used following Perkinsus specific primers: PerkITS-85 and PerkITS-750 ${ }^{7}$. We compared the nucleotide sequences of the ITS region of congeneric species registered in GenBank ( $P$. olseni, DQ370464-DQ370472 and DQ516703-DQ516715; $P$. honshuensis, DQ516697-DQ516702). Based on this comparison, we concluded that $P$. olseni and $P$. honshuensis could be differentiated by RFLP analysis using the restriction enzyme Dde I.

We performed PCR amplification in a total volume of $20 \mu \mathrm{L}$ containing $16 \mu \mathrm{L}$ of the DNA extract, dNTP Mixture (0.2 mm per nucleotide, TaKaRa, Japan), 0.75 $\mu \mathrm{M}$ of each primer, and 0.025 units $\mu \mathrm{L}$ TaKaRa Ex $\mathrm{Taq}^{\mathrm{TM}}$ (Hot start version; TaKaRa). The extract of cultured cells was diluted, and the amounts of DNA were adjusted to $10^{-8}-10 \mathrm{ng}$ for each PCR. The thermal conditions were $94^{\circ} \mathrm{C}$ for $5 \mathrm{~min}$ followed by 35 cycles of $95^{\circ} \mathrm{C}$ for $30 \mathrm{~s}, 55^{\circ} \mathrm{C}$ for $30 \mathrm{~s}$, and $72^{\circ} \mathrm{C}$ for $1 \mathrm{~min}$. This was followed by a single step at $72^{\circ} \mathrm{C}$ for $10 \mathrm{~min}$.

For RFLP analyses, $5 \mu \mathrm{L}$ of the PCR products were digested with 5-7 units of a restriction enzyme (Hinf I, Rsa I, or Dde I: Toyobo, Japan) in buffers provided from the manufacturer in a final volume of $10 \mu \mathrm{L}$ for $4 \mathrm{~h}$ at $37^{\circ} \mathrm{C}$. Following digestion the fragments were loaded onto a $1.5 \%$ agarose gel, stained with SYBR safe DNA gel stain (Invitrogen) and visualized with Safe Imager (Invitrogen). The fragments obtained from cultured trophozoites were purified using a DNA purification kit (QIAquick PCR purification kit, Qiagen) before being loaded on the gel, while those from the gill samples spiked with trophozoites and from the collected clams were loaded without purification.

\section{Results}

RFLP band patterns after Rsa I and Hinf I digestions that were deduced from nucleotide sequences were very similar between $P$. olseni and $P$. honshuensis. Expected fragment lengths after $R$ sa I digestion were 406, 193 and 74 bp for P. olseni and 413, 194 and 59 bp for $P$. honshuensis. Those after Hinf I were 363 and 159-151 pb (a combined band) for $P$. olseni and 371 and 150-145 (a combined band) for $P$. honshuensis.

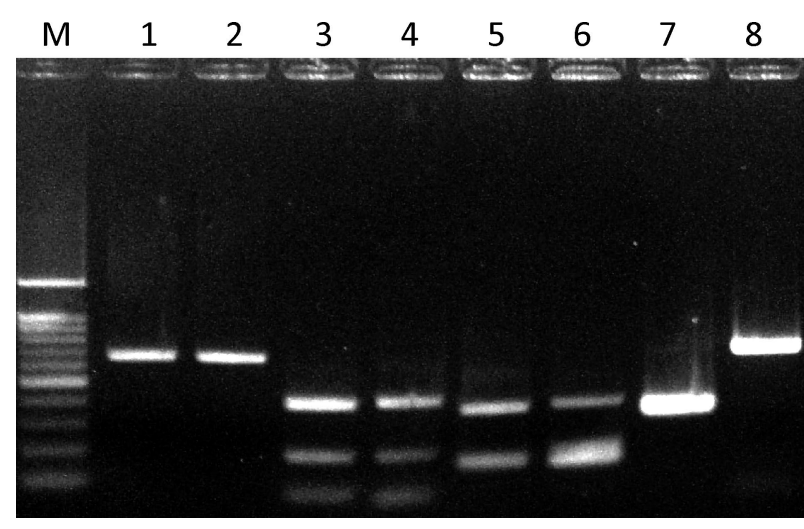

Fig. 1. PCR-RFLP electrophoretic patterns of $P$. olseni and $P$. honshuensis trophozoites digested with Rsa I, Hinf I, and Dde I. M, 100 bp marker; 1, undigested $P$. olseni; 2, undigested $P$. honshuensis; 3, $P$. olseni with Rsa I; 4, $P$. honshuensis with Rsa I; 5, P. olseni with Hinf I; 6, P. honshuensis with Hinf I; 7, P. olseni with Dde I; 8, P. honshuensis with Dde I.

Actual band patterns obtained from cultured trophozoites of $P$. olseni and P. honshuensis after Rsa I and Hinf I digestions were almost identical to the deduced patterns and very similar to each other (Fig. 1). In contrast, deduced RFLP band patterns after Dde I digestion were quite different between the two species. A single combined band of 349-324 bp, and a single band of $666 \mathrm{pb}$ were expected for $P$. olseni and $P$. honshuensis, respectively. Actual band patterns obtained from cultured trophozoites after Dde I digestion were almost identical to the deduced patterns (Fig. 1).

The fragments were detected at DNA concentrations $>10^{-1} \mathrm{ng}$ and $>10^{-5} \mathrm{ng}$ for $P$. olseni and $P$. honshuensis, respectively. When this method was applied to normal gill samples spiked with cultured trophozoites of the two species, the minimum detection levels were 100 cells per $10 \mathrm{mg}$ sample for $P$. olseni and one cell for $P$. honshuensis (Fig. 2). Although the length of fragments obtained from the spiked samples slightly differed from those deduced from their sequences, it is because the fragments were loaded on gels without purification; high salt concentration used for enzyme digestions affected the migration distances in gels. In the spiked samples, the resultant bands were faint or absent in some lanes that must have contained detectable amount of trophozoite DNA (lane 4 in Fig. 2 A and lane 8 in Fig. 2B). It is probably because trophozoites did not evenly disperse in the suspensions, as cultured trophozoites formed massive clusters containing hundreds of cells.

Using this method, we found that all of three Manila clams from a clam farm in Hiroshima and two out of four clams from a tidal flat in Oita, were infected with both $P$. olseni and $P$. honshuensis. Other two clams from Oita were found to be infected with $P$. olseni only. $P$. olseni was detected in only one of three Manila clams from a 


\section{A}
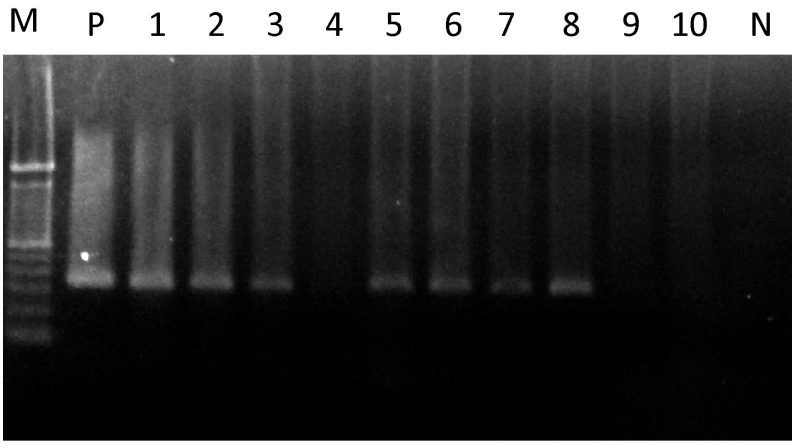

B
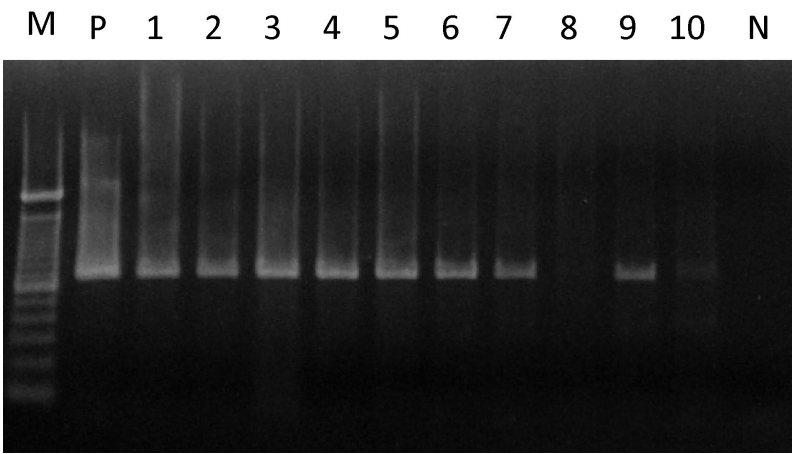

Fig. 2. PCR-RFLP electrophoretic profiles of PCR products of extracts from normal (= uninfected) gill samples spiked with $P$. olseni (A) and $P$. honshuensis (B) trophozoites. $\mathrm{M}, 100$ bp marker; $P$, trophozoites only; N, negative control. The number of the trophozoites subjected to extraction in lane 1 was $10^{9}$ (serially diluted $1: 10$ ).
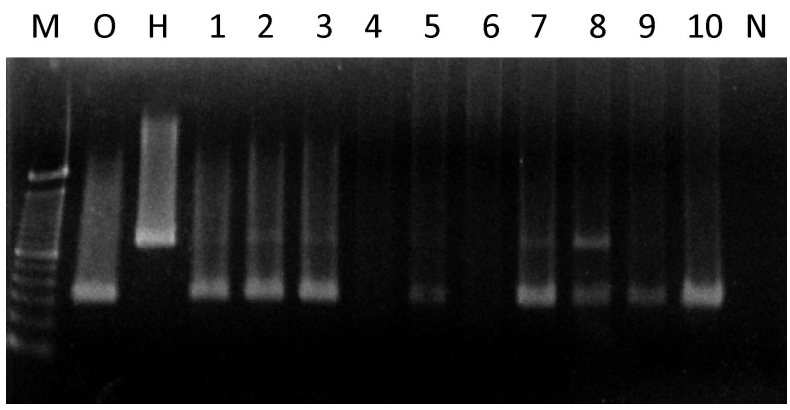

Fig. 3. PCR-RFLP analysis of Manila clams from three localities. $\mathrm{M}, 100 \mathrm{bp}$ marker; O, positive control $(P$. olseni); $\mathrm{H}$, positive control (P. honshuensis); 1-3, Hiroshima; 4-6, Kumamoto; 7-10, Oita.

tidal flat in Kumamoto, and $P$. honshuensis was not found in any clams from this site (Fig. 3).

\section{Discussion}

$P$. olseni can be distinguished from congeneric species by conducting PCR-RFLP with Hinf I and Rsa I ${ }^{6)}$. However, $P$. olseni and $P$. honshuensis were not distinguished using these enzymes. We developed a PCR-
RFLP method using the Dde I restriction enzyme that was used to distinguish these two species. We found that the intensity of $P$. olseni and $P$. honshuensis infection in Manila clams was approximated using the electrophoretic profile generated by PCR-RFLP. However, it was not achieved to accurately quantify the number of Perkinsus cells using this method, because the trophozoites formed massive clusters in medium. Quantitative surveillance of infection intensity are needed to estimate the impact of these parasites on clam populations. Given this, future research should focus on the development of methods for quantification. Very recently, species-specific mixed primers for $P$. marinus and $P$. honshuensis were developed by Moss ${ }^{8)}$ according to the OIE manual ${ }^{1}$. Species-specific PCR primer could be developed for $P$. honshuensis as well. By using species specific primers, semi-quantitative assays will become possible.

We used the new method to confirm the presence of parasites in Manila clams from several different localities around Japan. We found that Manila clams in the western Seto Inland Sea were infected with both $P$. olseni and $P$. honshuensis, though predominantly with P. olseni. Previously, P. honshuensis was reported only from Mie Prefecture. Detection of $P$. honshuensis had not been attempted in areas other than the original locality of the parasite until this study. Thus, this is the first report of $P$. honshuensis outside Mie. P. olseni may be widely distributed in other areas in Japan and in the Far East, as previously suggested ${ }^{5}$. However, more detailed investigations are needed to accurately determine the distribution of the two species. The Manila clams from Yatsushiro Bay appeared to be infected with $P$. olseni only. However, considering that the low infection levels of Perkinsus in the clams from the site and the limited number of samples, the absence of $P$. honshuensis in Yatsushiro Bay is not definitive.

\section{Acknowledgments}

The authors thank the Oita Prefectural Fisheries Institute for providing Manila clams. This study was partly supported by a Grant-in-Aid for Exploratory Research (21658069).

\section{References}

1) OIE (the World Organisation for Animal Health) (2009): Manual of diagnostic tests for aquatic animals, 6th edition. OIE, Paris. 2) Hamaguchi, M., Sasaki, M. and H. Usuki (2002): Jpn. J. Benthol., 57, 168-176. 3) Hamaguchi, M., N. Suzuki, H. Usuki and H Ishioka (1998): Fish Pathol., 33, 473-480. 4) Park, K. I. and K. S. Choi (2001): Aquaculture, 203, 9-22. 5) Dungan, C. F. and K. S. Reece (2006): J. Eukaryot. Microbiol., 53, 316-326. 6) Abollo, E., S. M. Casas, G. Ceschia and A. Villalba (2006): Mol. Cell Probes, 20, 323-329. 7) Cassa, S. M., Villalba, A. and Reece, K. S. (2002): Dis. Aquat. Org., 50, 51-65. 8) Moss J. A. (2007): Characteriza- 
tion of exotic pathogens associated with the suminoe oyster, Crassostrea ariakensis. Ph.D. Dissertation. Virginia Institute of Marine Science, College of William and Mary, Gloucester Point, Virginia, USA. $230 \mathrm{p}$. 